\title{
Isolation and Quantification of Dialkylmercury Species by Headspace Solid Phase Microextraction and Gas Chromatography with Atomic Emission Detection
}

\author{
Ana M. Oliveira, ${ }^{a}$ Gilmare A. Silva, ${ }^{b}$ Ronei J. Poppi ${ }^{b}$ and Fabio Augusto ${ }^{*, b}$ \\ ${ }^{a}$ Departamento de Ciências Naturais e Tecnologia, Universidade Estadual de Santa Cruz, \\ 45662-000 Ilhéus-BA, Brazil
}

${ }^{b}$ Instituto de Química, Universidade Estadual de Campinas, CP 6154, 13084-971 Campinas-SP, Brazil

\begin{abstract}
Foi desenvolvida uma metodologia para quantificar compostos dialquilmercúricos usando Microextração em Fase Sólida em Headspace (HS-SPME) e Cromatografia Gasosa com Detecção por Emissão Atômica (GC-AED). Os parâmetros para detecção de $\mathrm{Hg}$ foram otimizados usando planejamento fatorial e superfícies de resposta. Experimentos univariados foram empregados para determinar as condições de HS-SPME; as melhores fibras foram $75 \mu \mathrm{m}$ de Carboxen / PDMS e 65 $\mu \mathrm{m}$ de PDMS / DVB. Porém, as primeiras foram descartadas pela extensa degradação térmica dos analitos na dessorção. O procedimento otimizado permite detectar os analitos em amostras aquosas com limite de detecção de 1,7 e $0,2 \mathrm{ng} \mathrm{L}^{-1}$ para dimetil- and dietilmercúrio, respectivamente. As curvas analíticas são lineares nas faixas de 36 a $180 \mathrm{ng} \mathrm{L}^{-1}\left(\mathrm{Me}_{2} \mathrm{Hg}\right)$ e 38 a $190 \mathrm{ng} \mathrm{L}^{-1}\left(\mathrm{Et}_{2} \mathrm{Hg}\right)$, com limite de quantificação de $38 \mathrm{ng} \mathrm{L}^{-1}\left(\mathrm{Me}_{2} \mathrm{Hg}\right)$ e $29 \mathrm{ng} \mathrm{L}^{-1}\left(\mathrm{Et}_{2} \mathrm{Hg}\right)$ e coeficientes de correlação de 0,998 para $\mathrm{Me}_{2} \mathrm{Hg}$ e 0,999 para $\mathrm{Et}_{2} \mathrm{Hg}$.
\end{abstract}

A methodology to quantify dialkylmercury compounds using Headspace Solid Phase Microextraction (HS-SPME) and Gas Chromatography with Atomic Emission Detection (GC-AED) was developed. The parameters for $\mathrm{Hg}$ detection were optimized by factorial design and response surfaces. Univariate experiments were employed to determine the HS-SPME conditions; $75 \mu \mathrm{m}$ Carboxen / PDMS and $65 \mu \mathrm{m}$ PDMS / DVB were the best fibers. However, the former was excluded from further experiments due to extensive thermal degradation of analytes during desorption. The optimized procedure allowed detection of the analytes from aqueous samples with LOD of $1.7 \mathrm{ng} \mathrm{L}^{-1}$ and $0.2 \mathrm{ng} \mathrm{L}^{-1}$ for dimethyl- and diethylmercury, respectively. The analytical curves are linear in the range from 36 to $180 \mathrm{ng} \mathrm{L}^{-1}\left(\mathrm{Me}_{2} \mathrm{Hg}\right)$ and 38 to $190 \mathrm{ng} \mathrm{L}^{-1}\left(\mathrm{Et}_{2} \mathrm{Hg}\right)$, with LOQ of $38 \mathrm{ng} \mathrm{L}^{-1}\left(\mathrm{Me}_{2} \mathrm{Hg}\right)$ and $29 \mathrm{ng} \mathrm{L}^{-1}\left(\mathrm{Et}_{2} \mathrm{Hg}\right)$ and correlation coefficients of 0.998 for $\mathrm{Me}_{2} \mathrm{Hg}$ and 0.999 for $\mathrm{Et}_{2} \mathrm{Hg}$.

Keywords: HS-SPME, GC-AED, dimethylmercury, diethylmercury, factorial design

\section{Introduction}

Microorganisms can convert $\mathrm{Hg}^{+2}$ into organomercury compounds such as methylmercury, $\left(\mathrm{CH}_{3}\right) \mathrm{Hg}^{+}$, and dimethylmercury, $\left(\mathrm{CH}_{3}\right)_{2} \mathrm{Hg}$. These species are among the most dangerous environmental contaminants. Concentrations as low as $0.04 \mu \mathrm{g} \mathrm{L}^{-1}$ of methylmercury have been reported to be harmful to some species, and organomercuric species can be up to hundred times more toxic than the inorganic forms. ${ }^{1}$ Therefore, proper assessment of environmental mercury contamination demands sensitive and selective analytical methods capable of speciating the

*e-mail: augusto@iqm.unicamp.br several possible forms of this metal. Although procedures involving selective reduction of the analytes, coupled to detection techniques such as CV-AAS (Cold Vapor Atomic Absorption Spectrometry), have been employed, ${ }^{2}$ methodologies involving chromatographic separation of the $\mathrm{Hg}$ species by $\mathrm{HPLC},{ }^{3} \mathrm{CE}^{4}$ or, more frequently, $\mathrm{GC}^{5}$ are more usual. Traditionally, the ECD was the detector of choice ${ }^{6}$ however, since it is not specific for organomercury compounds, more recently devices such as the Atomic Emission Detector $(\mathrm{AED})^{7}$ have been favored. Compared to the ECD and other spectroscopic chromatographic detectors, AED has a remarkably higher sensitivity for organometallic compounds. ${ }^{8}$ However, especially for detection of metal compounds, a careful optimization of 
the GC-AED operational conditions has to be done: e.g., the He plasma support gas has to be simultaneously mixed with oxygen (to eliminate carbon deposits in the discharge tube generated from the fragmentation of organic eluates $)^{9}$ and hydrogen (to prevent the build-up of refractory metal oxides, causing peak tailing, loss of sensitivity and memory effects). ${ }^{10}$ The overall procedure for GC-AED optimization can be complex and time-consuming, considering the number of parameters (helium flow, pressures of the oxygen and hydrogen gases mixed into the plasma and the temperatures of transfer line and the plasma cavity) and the possible interdependence between these parameters (which demand multivariate optimization strategies).

Since some of the target species (especially $\mathrm{CH}_{3} \mathrm{Hg}^{+}$) are ionic, their conversion to volatile non-ionic derivatives is necessary before their separation and detection by GC. ${ }^{5}$ Also, isolation from the matrix and pre-concentration of the organomercuric compounds and their derivatives is necessary for their determination. Although the derivatization can be performed via Grignard reactions, ${ }^{11}$ simpler alkylation procedures using sodium tetraethyl-, tetrapropyl- or tetraphenylborate are presently preferred since they can be carried out directly in aqueous matrixes. ${ }^{12}$ However, conditions such as: nature and concentration of the alkylating agent, solution $\mathrm{pH}$, ionic strength of reaction media, reaction time and temperature ${ }^{13}$ should be optimized to achieve quantitative and reliable results. As for the isolation of organomercury compounds and their derivatives from aqueous and biological samples, Solid Phase Microextraction (SPME) can be regarded as one of the best available choices due to its inherent speed and reliability. ${ }^{14,15}$ Several operational variables also should be studied for the optimization of SPME procedures - extraction mode, nature of extracting fiber coating and others. ${ }^{16}$ Some of the variables affecting the performance of SPME - such as temperature and media ionic strength - also influence the course of the derivatization process. In most of the recent procedures for determination of organomercury species the derivatization and extraction steps are simultaneously optimized and carried out. ${ }^{17}$ However, considering the different physico-chemical processes involved in these steps, both direction and magnitude of the operational variable effects, common to both, can be radically different and their execution in parallel can reduce overall method sensitivity and precision. Consequently, separate extraction optimization and derivatization parameters can lead to a expressive improvement on the resulting complete analytical methodology. Therefore, in this work the conditions for headspace extraction by SPME of two neutral organomercury species - dimethyl- $\left(\mathrm{Me}_{2} \mathrm{Hg}\right)$ and diethylmercury $\left(\mathrm{Et}_{2} \mathrm{Hg}\right)$ - were established by univariate process while their detection by GC-AED was also optimized, employing a multivariate approach.

\section{Experimental}

\section{Gas Chromatograph}

GC-AED system was a HP-6850 gas chromatograph equipped with a G-2350A Atomic Emission Detector (Agilent Technologies, Wilmington, DE, USA) and fitted with a $25 \mathrm{~m} \times 0.32 \mathrm{~mm} \times 0.17 \mu \mathrm{m} \mathrm{HP}-1$ capillary column and a HP-7683 automated injector (Agilent). Helium was used both as carrier $\left(1.8 \mathrm{~mL} \mathrm{~min}^{-1}\right)$ and plasma support (make-up) gas; high purity hydrogen and oxygen were also used as plasma doping gases. GC-AED chromatograms were obtained monitoring the $253.65 \mathrm{~nm} \mathrm{Hg}$ emission line. For the optimization of the AED operation, the oven temperature was programmed from $45^{\circ} \mathrm{C}$ to $100{ }^{\circ} \mathrm{C}$ at $5{ }^{\circ} \mathrm{C} \mathrm{min}-1$. For these experiments, direct injection (using the automated injector) of $0.2 \mu \mathrm{L}$ (split ratio of 1:20) of alkylmercury solutions was used, with the injector kept at $260{ }^{\circ} \mathrm{C}$. For the manual SPME analysis, the injector was operated in splitless mode for $5 \mathrm{~min}$, and then purged with helium at

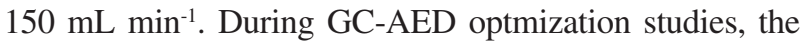
injector temperature was preliminarly set to $230{ }^{\circ} \mathrm{C}$ and the desorption time was $5 \mathrm{~min}$. For the HS-SPME optimization, the injector temperature was varied from $150{ }^{\circ} \mathrm{C}$ to $260{ }^{\circ} \mathrm{C}$; $150^{\circ} \mathrm{C}$ was selected for the remainder experiments. The oven temperature was programmed as follows: 2 min at $45^{\circ} \mathrm{C}$, then heated at $20{ }^{\circ} \mathrm{C} \min ^{-1}$ up to $105^{\circ} \mathrm{C}$.

\section{Chemicals and materials}

Acetone solutions $\left(6 \mu \mathrm{g} \mathrm{mL} L^{-1}\right)$ of $\mathrm{Me}_{2} \mathrm{Hg}$ and $\mathrm{Et}_{2} \mathrm{Hg}$ (Alpha Products, Houston, TX) were used for the AED optimization experiments. Analytical grade $\mathrm{NaCl}$ and acetone (Synth Química, Rio de Janeiro, Brazil) were also employed. The SPME fibers: $100 \mu \mathrm{m}$ PDMS (P100), $85 \mu \mathrm{m}$ polyacrylate (PACR), $65 \mu \mathrm{m}$ PDMS / DVB (DVB) and $75 \mu \mathrm{m}$ Carboxen / DVB (CAR) and the holder for manual operation were all purchased from Supelco (Bellefont, PA, USA). Prior to use, the fibers were conditioned according to supplier's recommendations. All extractions were performed with the samples contained in $16 \mathrm{~mL}$ septum-sealed glass vials (Supelco), and under $1200 \mathrm{rpm}$ magnetic agitation.

Optimization of the GC-AED system for mercury detection

A multivariate approach was adopted to optimize the main operational parameters: He make-up flow $\left(\mathbf{F}_{\mathrm{He}}\right)$; 
pressures of plasma doping oxygen $\left(\mathbf{p}_{\mathbf{O}_{2}}\right)$ and hydrogen $\left(\mathbf{p}_{\mathbf{H} 2}\right)$; temperatures of transfer line $\left(\mathbf{T}_{\mathbf{T L}}\right)$ and plasma cavity $\left(\mathbf{T}_{\mathbf{P C}}\right)$ of the GC-AED for mercury detection. Triplicate injections of dialkylmercury standard solutions under varied operational conditions arranged according to a $2^{5}$ factorial design experiment were carried out. The values for the parameters were: $\mathbf{F}_{\mathbf{H e}}=130$ and $200 \mathrm{~mL} \mathrm{~min}^{-1} ; \mathbf{p}_{\mathbf{0 2}}=$ 30 and $50 \mathrm{psi} ; \mathbf{p}_{\mathbf{H} 2}=10$ and $20 \mathrm{psi} ; \mathbf{T}_{\mathrm{TL}}$ and $\mathbf{T}_{\mathbf{P C}}=230^{\circ} \mathrm{C}$ and $280{ }^{\circ} \mathrm{C} . \mathrm{S} / \mathrm{N}$ ratios both for $\mathrm{Me}_{2} \mathrm{Hg}$ and $\mathrm{Et}_{2} \mathrm{Hg}$ peaks in all runs were defined as the response, and the effects of the variables were calculated using Matlab 6 (Mathworks Inc., Natick, MA, USA). Additional experiments were carried out to plot a $\mathbf{S} / \mathbf{N} \times \mathbf{F}_{\mathbf{H e}} \times \mathbf{p}_{\mathbf{O} 2}$ surface response to further assess the optimum values for these two variables.

\section{HS-SPME method for dialkylmercury compounds}

Conventional univariate studies were carried out to select the best SPME fiber, the desorption temperature and time, extraction temperature, ionic strength of the extracting media and extraction time. All experiments were performed in triplicate. To select the best fiber for the further experiments, $5 \mathrm{~mL}$ of a $6 \mathrm{ng} \mathrm{mL}^{-1}$ solution of the test compounds contained in $16 \mathrm{~mL}$ septum-sealed vials was stirred at ambient temperature for $5 \mathrm{~min}$ for sample/headspace equilibration. After the pre-equilibration a SPME fiber was exposed to the vial headspace for $10 \mathrm{~min}$, and the extracted analytes were immediately desorbed and analyzed by GC-AED. The effect of the desorption temperature was assessed for DVB and CAR fibers using the same procedure, but with injector temperatures ranging from $150{ }^{\circ} \mathrm{C}$ to $260{ }^{\circ} \mathrm{C}$. To study the effect of sample temperature, extractions of the test solution with DVB fiber and temperatures of $25^{\circ} \mathrm{C}, 45^{\circ} \mathrm{C}$ and $60{ }^{\circ} \mathrm{C}$ were carried out. The effect of the extracting media ionic strength was assessed using extractions with DVB fibers under the same conditions, but using as solvent for the test samples $\mathrm{NaCl}$ solutions with concentrations up to $36 \% \mathrm{~m} / \mathrm{v}$. Finally, the extraction profiles for $\mathrm{Me}_{2} \mathrm{Hg}$ and $\mathrm{Et}_{2} \mathrm{Hg}$ were evaluated with DVB extractions of test samples containing $9 \% \mathrm{NaCl}$ over the time range between $3 \mathrm{~min}$ and $45 \mathrm{~min}$.

Sensitivity, precision and limits of detection and quantitation for $\mathrm{Me}_{2} \mathrm{Hg}$ and $\mathrm{Et}_{2} \mathrm{Hg}$ were calculated with analytical curves estimated using extractions of test samples with concentrations ranging from $36 \mathrm{ng} \mathrm{L}^{-1}$ to $180 \mathrm{ng} \mathrm{L}^{-1}$ $\left(\mathrm{Me}_{2} \mathrm{Hg}\right)$ and $38 \mathrm{ng} \mathrm{L}{ }^{-1}$ to $190 \mathrm{ng} \mathrm{L}^{-1}\left(\mathrm{Et}_{2} \mathrm{Hg}\right)$ under the optimized GC-AED and HS-SPME conditions (GC-AED:

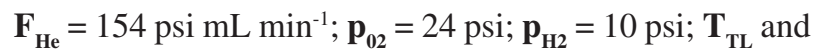
$\mathbf{T}_{\mathbf{P C}}=230^{\circ} \mathrm{C}$; HS-SPME: 15 min extraction with DVB fiber at $25^{\circ} \mathrm{C}$ and injector temperature of $150{ }^{\circ} \mathrm{C}$ ).

\section{Results and Discussion}

Table 1 shows the effects of the studied operational variables $\left(\mathbf{F}_{\mathbf{H e}}, \mathbf{p}_{\mathrm{O} 2}, \mathbf{p}_{\mathbf{H} 2}, \mathbf{T}_{\mathrm{TL}}\right.$ and $\left.\mathbf{T}_{\mathbf{P C}}\right)$ on the $\mathrm{S} / \mathrm{N}$ ratios measured for the $\mathrm{Et}_{2} \mathrm{Hg}$ chromatographic peak, obtained after processing the factorial design experiment. Since the behavior and tendencies observed for $\mathrm{Me}_{2} \mathrm{Hg}$ were equivalent to those of $\mathrm{Et}_{2} \mathrm{Hg}$, only the data and results for the later will be presented and discussed here. The second-order interactions between these variables are also shown in this table. To simplify the discussions, larger-order interactions were not considered. Adopting $95 \%$ as the confidence level, only the effects of $\mathbf{F}_{\mathbf{H e}}(-26.6)$ and $\mathbf{p}_{\mathbf{0 2}}(-24.1)$ on the $\mathrm{S} / \mathrm{N}$ ratios were significant. As they are negative, this indicates that the $\mathrm{S} / \mathrm{N}$ ratio increase when $\mathrm{F}_{\mathrm{He}}$ and $\mathrm{p}_{\mathrm{O} 2}$ are reduced in the studied range. As for the other variables, their effects were not representative and therefore they were fixed at the lower level for the remainder of this study. The presence of some statistically significant $2^{\text {nd }}$ order interactions $\left(\mathbf{p}_{\mathbf{H} 2} \times \mathbf{p}_{\mathbf{H} 2}\right.$ and $\left.\mathbf{T}_{\mathbf{T L}} \times \mathbf{T}_{\mathbf{P C}}\right)$ confirms the necessity of multivariate approaches for optimization of operational conditions in GC-AED systems, since they indicate that these variables do not act independently on the response.

To determine the optimum values of $\mathbf{F}_{\mathbf{H e}}$ and $\mathbf{p}_{\mathbf{0 2}}$, additional experiments were performed and the results

Table 1. Effects of helium make-up flow $\left(\mathbf{F}_{\mathrm{He}} / \mathrm{mL} \mathrm{min}^{-1}\right)$, pressure of oxygen $\left(\mathbf{p}_{\mathbf{O} 2} / \mathrm{psi}\right)$, pressure of hydrogen $\left(\mathbf{p}_{\mathrm{H} 2} / \mathrm{psi}\right)$, temperature of transfer line $\left(\mathbf{T}_{\mathrm{TL}} /{ }^{\circ} \mathrm{C}\right)$ and temperature of plasma cavity $\left(\mathbf{T}_{\mathbf{P C}} /{ }^{\circ} \mathrm{C}\right)$ on the GC-AED S/N ratio for $\mathrm{Hg}$ and second-order interactions ${ }^{\mathrm{a}}$ of these variable measured after factorial design experiments

\begin{tabular}{|c|c|c|c|c|c|c|}
\hline & & \multicolumn{5}{|c|}{ Variables } \\
\hline & & $\mathbf{F}_{\mathrm{He}}$ & $\mathbf{p}_{\mathrm{H} 2}$ & $\mathbf{p}_{\mathrm{O} 2}$ & $\mathbf{T}_{\mathrm{TL}}$ & $\mathbf{T}_{\mathbf{P C}}$ \\
\hline \multicolumn{2}{|c|}{$1^{\text {st }}$ Order Effects } & $-26.6^{b}$ & 5.7 & -24.1 & -1.8 & -0.6 \\
\hline \multirow{4}{*}{$\begin{array}{l}2^{\text {nd }} \text { Order } \\
\text { Interactions }\end{array}$} & $\mathbf{F}_{\mathrm{He}} \times \ldots$ & - & -5.9 & 1.0 & 4.8 & 5.7 \\
\hline & $\mathbf{p}_{\mathrm{H} 2} \times \ldots$ & -5.9 & - & -8.6 & 1.5 & 3.9 \\
\hline & $\mathbf{p}_{\mathrm{O} 2} \times \ldots$ & 1.0 & -8.6 & - & -0.5 & -0.7 \\
\hline & $\mathbf{T}_{\mathrm{TL}} \times \ldots$ & 4.8 & 1.5 & -0.5 & - & 14.7 \\
\hline
\end{tabular}

anteractions with $3^{\text {rd }}$ and $4^{\text {th }}$ orders not considered; Values in bold italic indicates statistically significance within a $95 \%$ confidence level. 
obtained fitted to a $\mathbf{S} / \mathbf{N} \times \mathbf{F}_{\mathbf{H e}} \times \mathbf{p}_{\mathrm{O} 2}$ response surface. This response surface is shown in Figure 1 . The $\mathbf{S} / \mathbf{N}$ ratio is maximized with lower pressures of $\mathrm{O}_{2}$ added to the plasma. For the He make-up flow, the dependence is more complex and there is a minimum for $\mathrm{F}_{\mathrm{He}} \approx 100 \mathrm{~mL} \mathrm{~min}^{-1}$; better $\mathbf{S} / \mathbf{N}$ ratios are obtained either with higher or lower He flows. Since the mechanism of signal generation in GC-AED is extremely complex, ${ }^{18}$ justification of these tendencies in terms of possible processes occurring in the plasma zone is impracticable. For the remaining experiments, $\mathbf{p}_{\mathbf{0 2}}$ was lowered only to 24 psi. Although better $\mathbf{S} / \mathbf{N}$ ratios are attainable using lower pressures of oxygen, during routine operation it was observed that this causes a substantial reduction of the lifetime of the detection cells, due to the build-up of carbonaceous deposits. For $\mathbf{F}_{\mathbf{H e}}, 154 \mathrm{~mL} \mathrm{~min}^{-1}$ was selected, to simultaneously maximize the $\mathbf{S} / \mathbf{N}$ ratio and the detection cell lifetime (which is also reduced with low He make-up flows).

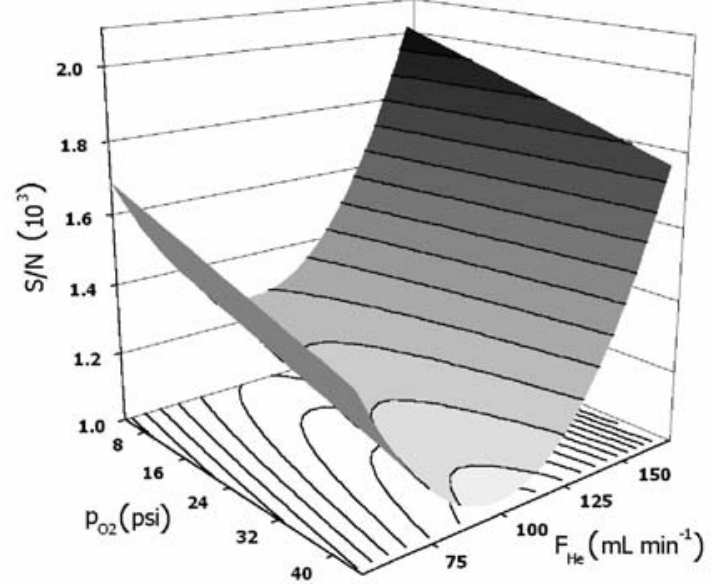

Figure 1. Response surface $\left(\mathbf{S} / \mathbf{N} \times \mathbf{p}_{\mathbf{O} 2} \times \mathbf{F}_{\mathbf{H e}}\right)$ for the $\mathrm{Et}_{2} \mathrm{Hg}$ chromatographic peak.

Figure 2 compares the average peak areas obtained after extractions using different SPME fibers. For both compounds, the order of extraction efficiency is PACR $<<$ P100 < DVB $<$ CAR. This particular sequence can be explained in terms of both the polarity and the volatility of the analytes. Dialkylmercury compounds are non-polar species; their affinity with a polar coating such as polyacrylate is expected to be low, which is confirmed by the limited extraction efficiency with this fiber. In contrast, the extracted amounts are substantially higher for P100 fibers, due to the non-polar coating (polydimethylsiloxane) of this fiber; which up to the present has been the fiber most frequently employed for extractions of the alkylmercury compounds. ${ }^{19-21}$ Higher efficiencies are possible with the DVB and CAR fibers. Since the coatings of these fibers are dispersions of solids (divinylbenzene and Carboxen 1006, respectivelly) in polydimethylsiloxane, both adsorption and partition occurs during the extraction..$^{22}$ For all fibers except CAR, extraction efficiency for $\mathrm{Et}_{2} \mathrm{Hg}$ was higher than that of $\mathrm{Me}_{2} \mathrm{Hg}$. Since the CAR fiber is selective for lighter, more volatile analytes, the improvement on the extracted amounts for $\mathrm{Me}_{2} \mathrm{Hg}$ was expected. Considering their improved extraction efficiencies towards the analytes, both CAR and DVB fibers were selected for the further experiments.

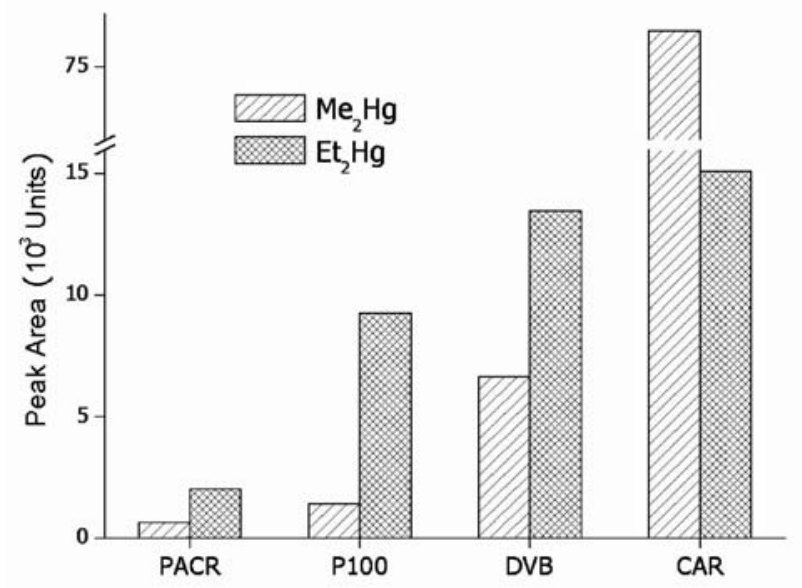

Figure 2. Peak areas for $\mathrm{Me}_{2} \mathrm{Hg}$ and $\mathrm{Et}_{2} \mathrm{Hg}$ found after HS-SPME using varied fibers.

The necessity of careful optimization of injector temperatures for chromatographic analyses of organomercury compounds is well known, since these analytes are thermally labile. ${ }^{23}$ The effect of desorption temperature on the peak areas is shown in Figures 3 and 4. The pattern of the variation of peak area of the analytes with the desorption temperature for DVB fibers is different from that of CAR: for both analytes on DVB, increasing the temperature causes a linear decrease in the peak areas. For CAR, the peak areas are maximized with desorption temperatures of $c a .220^{\circ} \mathrm{C}$. Some additional information can result from inspection of the chromatograms shown in Figure 4. The main feature of these chromatograms is the presence of peaks with $\mathrm{t}_{\mathrm{R}} \approx 1.40 \mathrm{~min}$, which are attributed to decomposition products of the dialkylmercury species (mainly $\mathrm{Hg}^{0}$ ). ${ }^{24}$ Comparing the chromatograms obtained with desorption temperature of $150{ }^{\circ} \mathrm{C}$, it can be seen that the decomposition peak is barely visible for DVB fiber, although it is still intense for CAR fibers. For higher injector temperatures, decomposition peaks appear for both fibers, being the more intense in the DVB chromatogram, and with a height similar to the $\mathrm{Me}_{2} \mathrm{Hg}$ peak in the CAR chromatogram. These observations suggest that the thermal degradation of dialkylmercury 
compounds is enhanced when they are adsorbed over the fiber coatings. Decomposition of $\mathrm{R}_{2} \mathrm{Hg}$ species adsorbed over carbon-based materials has already been described in the literature. ${ }^{25}$ For CAR, even at the comparatively low temperature of $150{ }^{\circ} \mathrm{C}$ artifact peaks already appear; the increase in the peak areas of the dialkylmercury compounds observed up to $\mathrm{ca} .220^{\circ} \mathrm{C}$ can be regarded as a result of improved desorption of the extracted analytes which, in that temperature range, seems to exceed the loss of adsorbed $\mathrm{R}_{2} \mathrm{Hg}$ caused by thermal decomposition. Compared to CAR, adsorption and desorption from DVB fibers is faster ${ }^{26}$ and the improvement on the desorption rate with temperature is expected to be marginal. Therefore, the only visible effect of higher desorption temperature on DVB is an increase on the rate of thermal degradation. Finally, from Figure 4 an expressive peak tailing on the chromatograms corresponding to CAR fibers is also evident for all studied desorption temperatures. This is the usual situation when these fibers are employed ${ }^{27}$ and it is also a consequence of the previously mentioned slow desorption of extracted materials. In view of the absence of significant thermal decomposition, DVB fibers were selected for the remaining experiments, even considering the higher extraction efficiency of CAR, especially towards $\mathrm{Me}_{2} \mathrm{Hg}$. The injector temperature was set to $150{ }^{\circ} \mathrm{C}$, to avoid loss of analytes by thermal decomposition.

As for the dependence between extraction temperature and extraction efficiency, it was observed that the efficiency decreases with the temperature. In the range between $25^{\circ} \mathrm{C}$ and $60{ }^{\circ} \mathrm{C}$, the peak areas were reduced in $81 \%$ $\left(\mathrm{Me}_{2} \mathrm{Hg}\right)$ and $73 \%\left(\mathrm{Et}_{2} \mathrm{Hg}\right)$. Higher temperatures lead to an increase the speed of transfer of volatile analytes from the sample to the headspace, but simultaneously the fiber coating/headspace distribution constant is reduced, ${ }^{28}$ causing
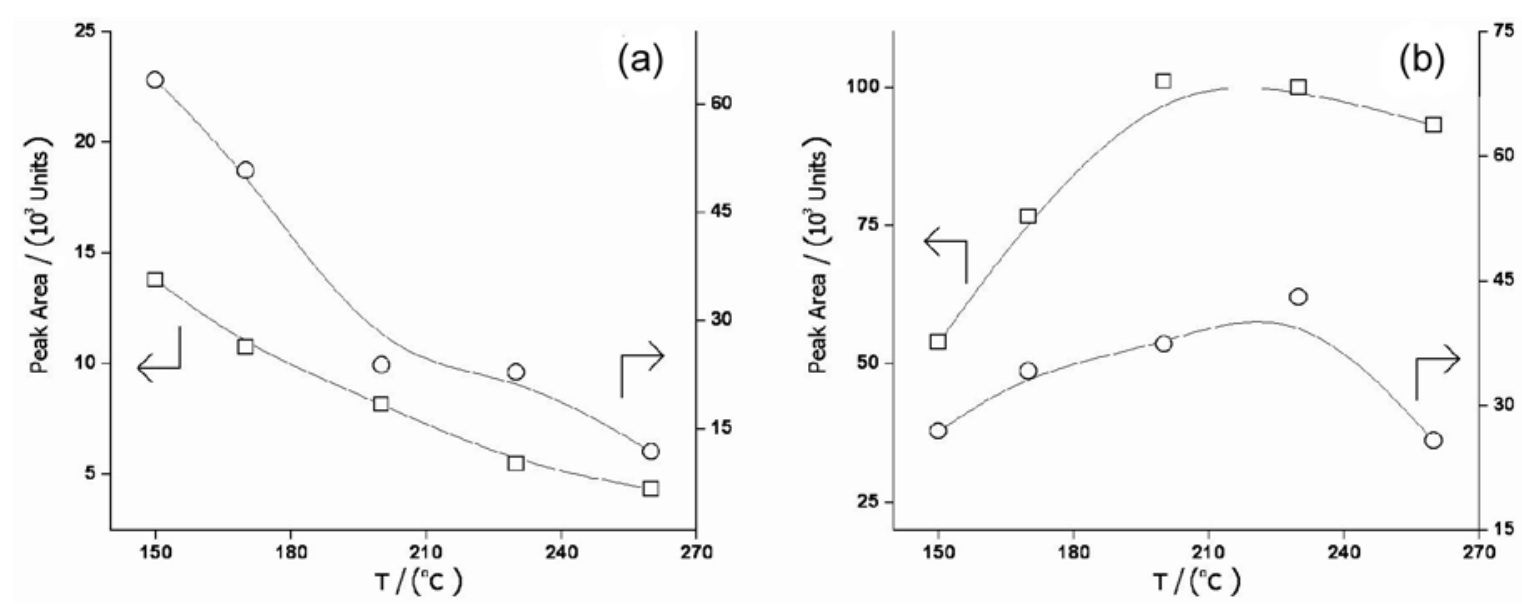

Figure 3. Dependence between peak areas and desorption temperature for $\mathrm{Me}_{2} \mathrm{Hg}(\mathrm{O})$ and $\mathrm{Et}_{2} \mathrm{Hg}$ ( $\square$ ), after $\mathrm{HS}-\mathrm{SPME}$ using DVB (a) and CAR (b) fibers.
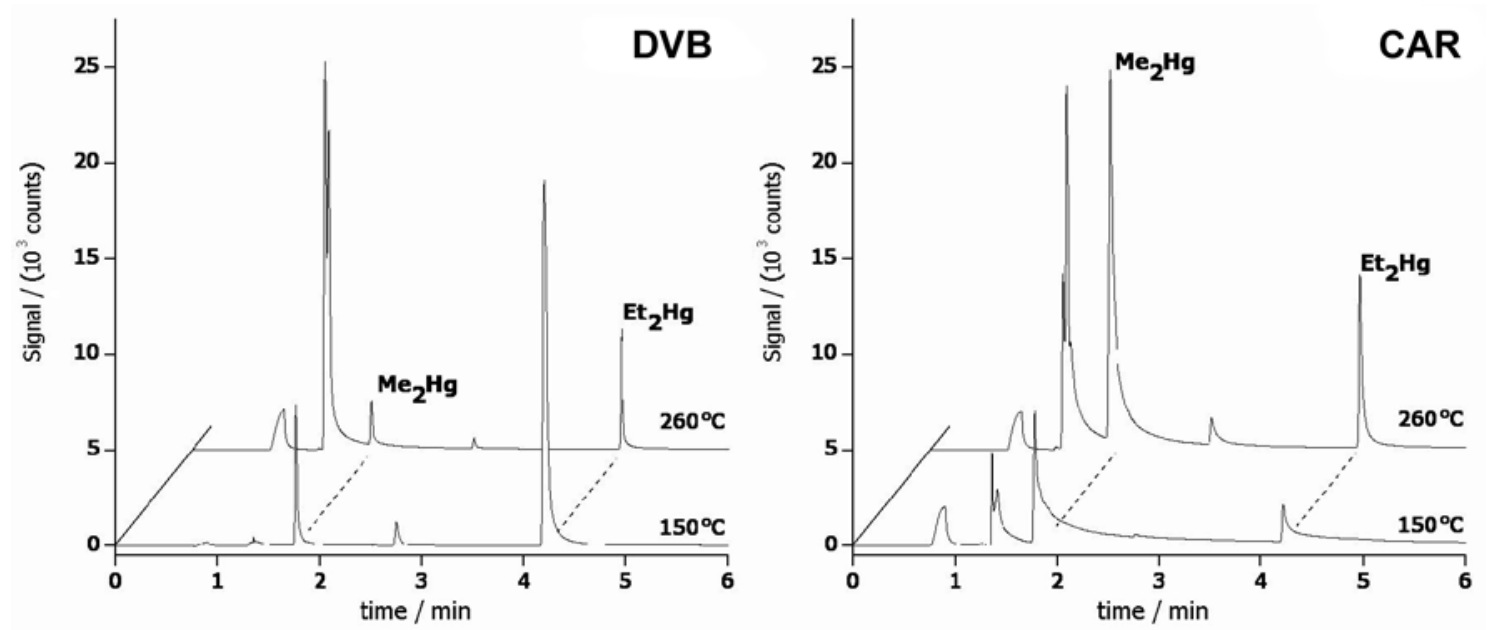

Figure 4. Typical GC-AED chromatograms for HS-SPME extractions using DVB or CAR fibers and desorption temperatures of $150{ }^{\circ} \mathrm{C}$ and $260{ }^{\circ} \mathrm{C}$. 
for the observed behaviour. Therefore, all remaining work was carried out at the laboratory temperature, $(25 \pm 1){ }^{\circ} \mathrm{C}$. The effect of different $\mathrm{NaCl}$ concentrations in the extracting media is shown in Figure 5. For $\mathrm{Et}_{2} \mathrm{Hg}$, the extraction efficiency is roughly constant up to $18 \% \mathrm{NaCl}$, decreasing for more saline media; for $\mathrm{Me}_{2} \mathrm{Hg}$, efficiency peaks at $9 \%$ $\mathrm{NaCl}$. The usual behavior in HS-SPME, especially for non-polar analytes such as dialkylmercury compounds, is a constant increase of the extraction efficiency with the $\mathrm{NaCl}$ concentration. ${ }^{28}$ The different effect of $\mathrm{NaCl}$ concentration seen here was already been reported for SPME, ${ }^{29}$ but was attributed to the quenching of the derivatization process, ethylation. The appearance of a similar effect here shows that an excessive $\mathrm{NaCl}$ concentration in the media can also reduce the extraction efficiency, independent of its effect upon the alkylation of organomercury species. This effect can be attributed to the possible formation of ionic, nonvolatile and stable complexes between the $\mathrm{R}_{2} \mathrm{Hg}$ species and chloride ions. ${ }^{30}$ Higher concentrations of $\mathrm{NaCl}$ would shift the reaction equilibrium towards the formation of the complex, decreasing the concentration of free extractable dialkylmercury species. Considering the observed profiles, $9 \% \mathrm{NaCl}$ was added to the extracting media for the remainder of this work. Extraction time profiles obtained for HS-SPME of dialkylmercury solutions containing $9 \%$ $\mathrm{NaCl}$ revealed that equilibrium is reached after $c a .15 \mathrm{~min}$ extraction for $\mathrm{Me}_{2} \mathrm{Hg}$ and between $20 \mathrm{~min}$ and $30 \mathrm{~min}$ for $\mathrm{Et}_{2} \mathrm{Hg}$. However, for practical reasons, since the increase in the area of the later after $15 \mathrm{~min}$ is negligible, $15 \mathrm{~min}$ was adopted as the extraction time.

The sensitivity, precision and detectability for $\mathrm{R}_{2} \mathrm{Hg}$ quantitation using the optimized extraction and detection

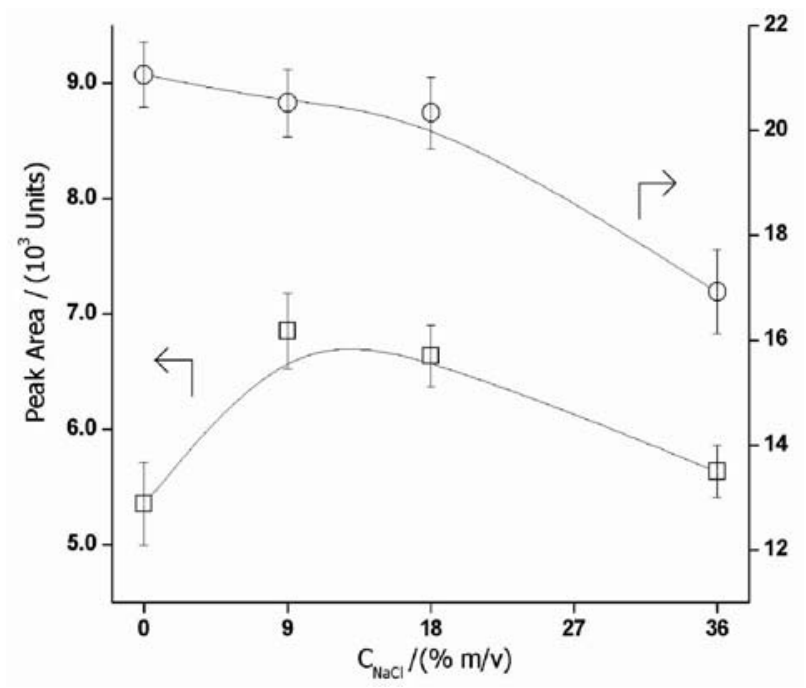

Figure 5. Dependence between peak areas and $\mathrm{NaCl}$ concentration in the samples for $\mathrm{Me}_{2} \mathrm{Hg}(\mathrm{O})$ and $\mathrm{Et}_{2} \mathrm{Hg}(\square)$, after HS-SPME using DVB fibers. method can be evaluated from the data presented on Table 2. The precision for both analytes in the concentration range studied, expressed as the regression coefficients of the analytical curves, can be regarded as adequate $\left(\mathrm{r}=0.998\right.$ for $\mathrm{Me}_{2} \mathrm{Hg}$ and 0.999 for $\mathrm{Et}_{2} \mathrm{Hg}$ ). The $\mathbf{F}$-values for the regression lines, 715 and 2002, respectively, are higher than the $95 \%$ significance critical value of 19.2 , confirming the linearity of the data in this range. The limits of detection and quantitation, $1.7 \mathrm{ng}(\mathrm{Hg}) \mathrm{L}^{-1}$ for $\mathrm{Me}_{2} \mathrm{Hg}$ and $0.2 \mathrm{ng}(\mathrm{Hg}) \mathrm{L}^{-1}$ for $\mathrm{Et}_{2} \mathrm{Hg}$, are adequate for application to most of the environmental or clinical samples ${ }^{29}$ and in general better than figures reported for similar studies regarding determination of $\mathrm{Hg}$ species in water samples: ${ }^{32}$ e.g., $412 \mu \mathrm{g}(\mathrm{Hg}) \mathrm{L}^{-1}$ (diphenylmercury using SPME-HPLC$\mathrm{UV}) ; 3.1 \mathrm{ng}(\mathrm{Hg}) \mathrm{L}^{-1}$ (methylmercury using SPME-GC-MS) and $3.7 \mathrm{ng}(\mathrm{Hg}) \mathrm{L}^{-1}$ (generic alkylmercury using SPMEGC-ICPMS).

Table 2. Figures of merit for the determination of $\mathrm{R}_{2} \mathrm{Hg}$ using the optimized HS-SPME / GC-AED method: slopes a, intercepts b, correlation coefficients $r$ and regression standard errors $s_{\text {tot }}$ of the analytical curves, corresponding regression F-test parameter $\mathrm{F}$ and absolute limits of detection $\mathrm{LOD}^{\mathrm{a}}$ and quantitation $\mathrm{LOQ}^{\mathrm{b}}$, in $\mathrm{ng}(\mathrm{Hg}) \mathrm{L}^{-1}$

\begin{tabular}{lcc}
\hline Parameter & $\mathrm{Me}_{2} \mathrm{Hg}$ & $\mathrm{Et}_{2} \mathrm{Hg}$ \\
\hline $\mathrm{a}$ & $1.45 \pm 0.05$ & $14.6 \pm 0.5$ \\
$\mathrm{~b}$ & $34 \pm 6$ & $-49 \pm 58$ \\
$\mathrm{r}$ & 0.998 & 0.999 \\
$\mathrm{~s}_{\text {tot }}$ & 6.2 & 55.6 \\
$\mathrm{~F}$ & 715 & 1002 \\
LOD $^{\mathrm{a}}$ & 1.7 & 0.2 \\
LOQ $^{\mathrm{b}}$ & 38 & 29 \\
\hline
\end{tabular}

${ }^{\mathrm{a}}$ Estimated from signal-to-noise $(\mathbf{S} / \mathbf{N})$ ratio and defined as the concentration of analyte generating a peak with height equal to $3 \times(\mathbf{S} / \mathbf{N})^{31}$; ${ }^{b}$ Estimated from the regression data and defined as $10 \times \mathbf{s}_{\text {tot }} / \mathbf{a} .{ }^{31}$

\section{Conclusions}

Headspace SPME together with GC-AED was found to be specially suited for isolation, separation and detection of dialkylmercury compounds. The optimization of the operational parameters affecting the AED operation for $\mathrm{Hg}$ detection provided a significant enhancement of the sensitivity and detectability for this element. Coupled with HS-SPME, this technique is able to detect and quantify amounts of these analytes in the $\mathrm{ng} \mathrm{L}^{-1}$ range. As for the HS-SPME method, use of PDMS-DVB fibers provide a significant enhancement of the sensitivity, compared to the PDMS fibers usually employed. The thermal instability of these species point to the need of a careful optimization of the extraction parameters, notably the desorption temperature and time. 


\section{Acknowledgments}

This work was funded by the Fundação de Amparo à Pesquisa do Estado de São Paulo (FAPESP). Scholarships for A.M.O and G.A.S. were granted by the Conselho Nacional de Desenvolvimento Científico e Tecnológico (CNPq).

\section{References}

1. Boening, D. W.; Chemosphere 2000, 40, 1335.

2. Limaverde Filho, A. M.; Campos, R. C.; Quim. Nova 1999, 22, 477.

3. Evans, O.; McKee, G. D.; Analyst 1987, 112, 983.

4. Carro-Diaz, A. M.; Lorenzo-Ferreira, R. A.; Cela-Torrijos, R.; J. Chromatogr. A 1996, 730, 345.

5. Morita, M.; Yoshinaga, J.; Edmonds, J. S.; Pure Appl. Chem. 1998, 70, 1585.

6. Westlöö, G.; Acta Chim. Scand. 1968, 22, 2277.

7. Pereiro, I. R.; Diaz, A. C.; Anal. Bioanal. Chem. 2002, 372, 74.

8. Paneli, M.; Rosenberg, E.; Grasserbauer, M.; Ceulemans, M.; Adams, F.; Fresenius J. Anal. Chem. 1997, 357, 756.

9. Valente, A. L. P.; Uden, P. C.; J. High Resolut. Chromatogr. 1993, 16, 275 .

10. Lobinski, R.; Dirkx, W.M.R.; Ceulemans, M.; Adams, F. C.; Anal. Chem. 1992, 64, 159.

11. Estes, S. A.; Uden, P. C.; Barnes, R. M.; Anal. Chem. 1982, 54, 2402.

12. Minganti, V.; Capelli, R.; de Pellegrini, R.; Fresenius J. Anal. Chem. 1995, 351, 471.

13. Grinberg, P.; Campos, R. C.; Mester, Z.; Sturgeon, R. E.; J. Anal. At. Spectrom. 2003, 18, 902.

14. Mester, Z.; Sturgeon, R.; Pawliszyn, J.; Spectrochim. Acta B 2001, 56, 233.

15. Rodil, R.; Carro, A. M.; Lorenzo, R. A.; Abuin, M.; Cela, R.; J. Chromatogr. A 2002, 963, 313.
16. Pini, G. F.; Brito, E. S.; García, N. H. P.; Valente, A. L. P.; Augusto, F.; J. Braz. Chem. Soc. 2004, 15, 267.

17. Carro, A. M.; Neira, I.; Rodil, R.; Lorenzo, R. A.; Chromatographia 2002, 56, 733.

18. Risby, T. H.; Talmi, Y.; CRC Crit. Rev. Anal. Chem. 1983, 14, 231.

19. Botana, J. C.; Rodríguez, R. R.; Díaz, A. M. C.; Ferreira, R. A. L.; Torrijos, R. C.; Pereiro, I. R.; J. Anal. At. Spectrom. 2002, 17, 904.

20. Diez, S.; Bayona, J. M.; J. Chromatogr. A 2002, 963, 345.

21. Tutschku, S.; Schantz, M. M.; Wise, S. A.; Anal. Chem. 2002, $74,4694$.

22. Mani V. In Applications of Solid Phase Microextraction; Pawliszyn, J., ed.; RSC: Cambridge, 1999, ch. 5.

23. Bloom, N. S.; Colman, J. A.; Barber, L.; Fresenius J. Anal. Chem. 1997, 358, 371.

24. Waring, C. E.; Pellin, R.; J. Phys. Chem. 1967, 71, 2044.

25. Liang, L.; Horvat, M.; Bloom, N. S.; Talanta 1994, 41, 371.

26. Górecki, T.; Yu, X.; Pawliszyn, J.; Analyst 1999, 124, 643.

27. Oliveira, A. M.; Pereira, N. R.; Marsaioli Jr., A.; Augusto, F.; J. Chromatogr. A 2004, 1025, 115.

28. Valente, A. L. P.; Augusto, F.; Quim. Nova 2000, 23, 523.

29. Cai, Y; Bayona, J. M.; J. Chromatogr. A 1995, 696, 113.

30. Sinha, S. P.; Inorg. React. Mech. 2000, 2, 33.

31. Ribani, M.; Bottoli, C. B. G.; Collins, C. H., Jardim, I. C. S. F.; Melo, L. F. C.; Quim. Nova 2004, 27, 771.

32. Gbatu T. P.; Sutton K. L., Caruso J. A.; Anal. Chim. Acta 1999, 402, 67; Centineo, G.; González, E. B.; Sanz-Medel, A.; J. Chromatogr. A 2004, 1034, 191; De Smaele, T.; Moens, T.; Sandra, P.; Dams, R.; Mikrochim. Acta 1999, 130, 241.

Received: September 19, 2007 Web Release Date: June 13, 2008

FAPESP helped in meeting the publication costs of this article. 